\title{
Participation of Women in the United States Congress: 1917-2011.
}

\author{
Magdalena Chojnacka \\ Andrzej Frycz Modrzewski Krakow University (AFMKU) \\ Faculty of International Relations \\ mchojnacka@poczta.onet.pl
}

\section{SUMMARY}

The last decades have carried changes in the legal and social position of women bearing enfranchisement, a new approach to women's education, and their increased participation in the job market. This article outlines the historical participation of women on the political scene of the United States between the years of 1917-2011 including an analysis of the situation in the individual states. Furthermore, it analyses what types of positions have been held by women in the American Government Administration including the most prestigious ones of the Speaker and the Secretary of State. It also introduces Hilary Rodham Clinton, the first woman ever to run in the presidential elections 2008. This analysis reveals that women are still underrepresented in the federal-level positions which makes it difficult for them to influence the quality of the lawmaking and results in a difficulty to promote such decisions that are important for the women themselves.

Keywords: Women, Unites States Congress, House of Representatives, Senate, politics

\section{INTRODUCTION}

Recent decades have brought significant changes in social and legal situation of women. They gained voting rights; there were great shifts in the attitudes towards education of women and their participation in the labour market. Currently, women constitute half of all students at American universities; that refers to all studied subjects both humanities and sciences. There are more and more women gaining employment both in private and governmental sectors. Still, however, not many women reach executive positions or become board members. There is a disproportion between earnings of men and women working full-time. For example, in 2008 women's average pay was $638 \$$ per week while men earned 798\$ per week; therefore, women's incomes were around $20 \%$ smaller than men's (U.S. Department of Labor, 2009).

\section{WOMEN REPRESENTATIVES AND SENATORS}

Women's participation in the U.S. political life has gradually increased in recent years. At the same time, however, the number of women holding seats in the US Congress has not exceeded $18 \%$. Originally, this situation stemmed from the traditional role of a woman, who was mainly seen as a housewife and would not follow any professional career. Jeanette Rankin, a Republican from Montana, was the first female member of Congress and was elected to the House of Representatives in 1916. She tried to win a congressional seat even before the Nineteenth Amendment granted women the right to vote. Jeannette was the member of the House twice: from 1917 to 1919 and 1941 to 1943. She was involved in the woman suffrage movement which fought for women's voting right. She contributed to granting women the right to vote in 1914 in Montana. As she expressed in her electoral programme, she pursued the ratification of an Amendment granting women the right to vote. She was the only member of the House of Representatives who voted against the US entering the World War II after Japan's attack on Pearl Harbor (Lopach and Luckowski, 2005).

The first woman to serve in the US Senate was Rebecca Latimer Felton, a Democrat who was sworn in on November 21st, 1921, and served only one day to fill the position left vacant by her deceased husband. She was also the oldest woman in history to be appointed to the Senate as she served at the age of 87 . Her seat was later given to a man by authorities of the state of Georgia (Talmadge, 1960). In the past many women served in the Congress succeeding their late husbands in office, a phenomenon known as widow's mandate. It was there to give a state an adequate amount of time to appoint a successor or to organise special elections. There were cases of women who were nominated to be the candidates to the US Congress; some of them filled the seats of their deceased husbands until the end of the term. Most of them, however, rarely built up their own political reputation and mainly represented interests of their late husbands.

There were cases when a woman won a new seat even after her widow's mandate tenure came to the end. This is how Edith Nourse Rogers, a Republican from Massachusetts gained her seat in the House of Representatives in 1925 where she served continuously until her death in 1960. During World War I she was a member of Young Men's Christian Association, and American Red Cross. Moreover, she worked as a volunteer in a hospital for veterans. During her long tenure in the House of Representatives, she was twice the Chairman of the Senate Committee on Veterans' Affairs, from 1947 to 1949 and 1953 to 1955 . She was against child labour; she fought for a 48 hour workweek for women and for the rule equal pay for equal work. Edith was the longest serving woman in the US Congress (U.S. House of Representatives, 2006).

A similar case is the Senate career of Hattie Wyatt Caraway, a Democrat from Arkansas who gained her seat in 1931. She was elected again in 1932 and 1938. Hattie was appointed by the governor 
of Arkansas to take a seat in the Senate on December 9, 1931 and complete her husband's term. On the January 12, 1932 she won a special election, becoming the first woman elected to the US Senate. As a senator she was a prohibitionist and supported Roosevelt's economic policies (Malone, 1989). Until 2001 there were only 3 women in the House of Representatives who succeeded their late husbands in office (American Political Leaders, 2005).

The observers of the history of American legislation could note two moments of a significant increase in the number of women in Congress. First time it took place between 1929 and 1931, when as many as 9 women became members of the House of Representatives. As this happened during the presidency of Franklin Delano Roosevelt, probably not without significance was the fact that his wife Eleonora Roosevelt was a staunch advocate of social and political reforms and an independent thinker herself; she was known for her support for any social initiatives that aimed for propelling women into highprofile positions (Green, 1980).

Second period of more intense participation of women in political life can be observed between 1993 and 1995. 1992 accounts for a unique electoral year and is widely known as „Women's Year”. In this period a record number of women run for Congress and as many as 48 women were elected to the House of Representatives and 7 to the Senate (Mildred, 2008). This phenomenon was determined by a few important factors. Many politicians ended their political careers and retired which led to their parliamentary seats becoming vacant. Moreover, there could be seen a significant increase in development of organisations facilitating women to finance their election campaigns, which in the USA are very costly. One of such organisations is Emily's List- Early Money Is Like Yeast founded by Ellen Malcolm. The organisation aims to raise money and search for sponsors who could help finance election campaigns for female Democratic candidates. It was established in 1985 and today is one of the biggest political action committees that helped many women organise an effective campaign and consequently, take their seats in the Congress (Emily's List, 2011).

Female Republican Candidates are supported by WISH List - Women in the Senate and House. This organisation was founded in 1992 and its activity is similar to the one of Emily's List's. It helps women gain their mandates in local, state and federal governments. Apart from financial support to the candidates it can also provide legal advice and training (Women in the Senate and House, 2011).

In first years of women's presence in the Congress, their ranks would grow rather slowly. There were only 3 women senators before the 90 s. It was in 1993 when that number increased to 7 . Until 1990 only 6 women remained for 6 year tenure. In 2003 in the Senate there were already 14 women. Three states: California, Maine and Washington were represented exclusively by women. In 2009 that number grew to 18 which made up for $18 \%$ of the whole number of senators (Mildred, 2008).
A similar situation could be observed in the House of Representatives, where initially the representation of women was minimal. The increase could be seen only in 1929 when 9 women gained their seats, 4 more than in previous Congress. This number was doubled in 1961 and since 1981 there has been stable and gradual increase in women being in office. Currently this number is 77 which constitute $17.7 \%$ of all representatives .Currently 95 women serve in the 111th Congress, $17.7 \%$ of all its members. It is a 7\% increase compared to the period 1993-1995 when 55 women were members of both houses of U.S. Congress (Mildred, 2008).

By 2009 there were 249 women in the Congress, 158 of which were Democrats and 88 Republicans. 246 filled seats in the House of Representatives, 28 in Senate, 7 in both houses of Congress. Out of 218 women who sat in the House of Representatives 38 were elected under widow's mandate and 16 of them ran successfully for reelection (Mildred, 2008).

The analysis of the number of women serving in the House of Representatives from 1917 to 2011 reveals that only few states had female representation that would consist of more than 10 people. These states were: California 32, New York 20, Illinois 13, Florida 11, and Ohio 10 (Biographical Directory of the U.S. Congress, 2011).

Only two states, Louisiana and Maine, have been represented in the Senate by more than two women. More than half of the states had no women serving in the Senate. Alaska and North Dakota have been represented by women in the Senate, but not in the House of Representatives. Delaware, Iowa, Mississippi and Vermont have not had any female representatives in the Congress yet. Throughout the U.S. history 21 states have been represented by women who served both in the Senate and in the House of Representatives (Biographical Directory of the U.S. Congress, 2011).

It is worth to notice that before 1964 all women serving in the Congress were white. The first woman of colour elected to the House of Representatives was Patsy Takemoto Mink, an Asian American Democrat from Hawaii. Patsy served from 1965 to 1977 and 1990 to 2002. During her first tenure she became the principal author of the legal Act known as Title IX of the Education Amendments of 1972. The act prohibits discrimination based on sex in education programs and activities that receive federal financial assistance. Title IX amended Title VI of the Civil Rights Act of 1964, which prohibited discrimination based on race, colour or national origin. After Patsy's death the Title $I X$ was renamed the Patsy T. Mink Equal Opportunity in Education Act, in honour of her contribution in support of equality. The Act, however, is commonly referred to as Title IX (U.S. House of Representatives, 2006).

By 2009 there were 40 women of colour in the Congress, 32 of whom gained their mandates as late as after 1990. Until now only two of these ladies were the members of the Republican Party. Hitherto, 39 women filled seats in the House of 
Representatives, only one, Carol Moseley Braun, a Democrat from Illinois, was a member of the Senate from 1993 to 1999. After the completion of her term in the Senate and an unsuccessful attempt of re-election, she served as an US Ambassador to New Zealand and Samoa from 1999 to 2001 (U.S. Senate, 2011).

\section{WOMEN IN LEADERSHIP POSITIONS}

Still, until now, women gain their high-profile federal positions mainly through appointment rather than election. For example, before 2009 only 43 women were given posts in government administration. Posts most often filled by women were: Secretary of Labor (7), Secretary of Health and Human Services (5), U.N. Ambassador (3), U.S. Trade Representative (3), Chair, Council of Economic Advisers (3). Three women were appointed Secretaries of State: Madeleine Albright during Clinton's presidency, Condoleezza Rice in G.W. Bush administration and currently Hillary Rodham Clinton working in Barack Obama's office. As for now, only one woman, Janet Reno, took a post of Attorney General in Clinton's Cabinet (Center for American Women and Politics, 2011).

The largest number of women held government posts during Bill Clinton's presidency, between the years 1993 and 2001. There were as many as 13 women who were given official positions out of 25 coming from the Democratic Party. This was when the first woman was appointed Secretary of State, the head of U.S. diplomacy. In Barack Obama's cabinet 7 women have served in top public offices so far. As for the Republican Party the largest number of women serving in public administration could be seen during the G.W. Bush's presidency. It was the total of 8 women out of all 18 appointed by the Republican Party (Center for American Women and Politics, 2011).

On 4 January 2007, exactly 90 years after the inauguration of the first U.S. Congresswoman, the first woman was appointed to hold the prestigious office of Speaker, the presiding officer of the House of Representatives. That person was Nancy Pelosi from California, who has continuously been the member of the House of Representatives since January 1987. In 2001 she became the House Minority Whip, second-in-command to Minority Leader of the U.S. House of Representatives. Two years later, after the Minority Leader Dick Gephardt stepped down, she took over his post. After the victory of Democrats and when they gained the parliamentary majority, Nancy Pelosi took over as Speaker. The Speaker is a leadership position in the majority party and second in the U.S. presidential line of succession after the Vice President under 1947 Presidential Succession Act (Biographical Directory of the U.S. Congress, 2011). The Speaker is thus the highest-ranking member of the Congress.

In 2008 presidential elections for the first time in U.S. history a woman, Senator Hillary Rodham Clinton, decided to fight for Democratic presidential nomination. So far only one woman, Geraldine Ferraro in 1984, was a Vice Presidential candidate when Democratic presidential candidate Walter Mondale selected Ferraro to be his running mate in the upcoming election. They, however, were defeated by incumbent Ronald Reagan. Democrat's decision was dictated by their desire to raise women's and minority groups' votes as Geraldine was an Italian American (Gadziński, 2005).

Hillary Rodham Clinton was considered the favourite, especially in women's circles. She was defeated, however, by Barack Obama, who secured the votes of the majority of electors. Obama received 2,201 votes compared to 1,896 received by Hillary, which gave him victory with the result of $53.6 \%$ over Hilary's $46.2 \%$. Nomination was guaranteed by receiving 2,118 votes (Election Center, 2008). Hillary won in 22 states: South Dakota, Puerto Rico (Puerto Rico is an unincorporated territory of the United States of America with a broad autonomy. Its citizens are American Passport holders and the right to freely settle on the territory of the US. They can not, however, participate in the presidential or congressional elections; they only have the right to vote in primary elections (Puerto Rico, 2011)), Kentucky, West Virginia, Indiana, Pennsylvania, Rhode Island, Texas, Ohio, California, Arizona, New Mexico, New York, Arkansas, Massachusetts, New Jersey, Oklahoma, Tennessee, Florida, Nevada, Michigan and New Hampshire (Election Center, 2008).

Clinton lost the race for the Democratic nomination in spite of strong advantages. She spent 8 years in the White House as the First Lady, another 8 years she served as a Senator for New York. Hillary has been the only First Lady in U.S history who was a candidate to the Senate and the first female Senator to represent New York who remained in her seat continuously from her swearing in on 3 January 2001 to the day she resigned on 21 January 2009 (ClintonRodham, 2003).

It is difficult to answer the question what were the immediate causes of Mrs Clinton's defeat in the presidential elections. Did she lose because she is a woman or because her opponent was the charismatic Obama? It cannot be said that her gender did not play a role in the elections; there were many biting remarks from voters or TV commentators regarding Mrs Clinton being a woman. However, referring to the words of the Washington Post commentator, Anne Kornblut, one of the main problems of Hilary's campaign team was their inability to present a convincing model of female leadership in politics. A man feels comfortable and natural participating in political life. He does not need to prove anything.

Mrs Clinton, on the other hand, had to try and shed the burden of being female (Bosacki, 2010). It is easy to note, however, that Hillary can be perceived as a controversial figure. She could be admired for her involvement in the internal affairs of the United States or she could be perceived as an unfriendly, 
calculated and narrow-minded feminist, who only cares about her own career (Milewski, 2010).

First Ladies, who engaged in their husbands' politics, and influenced their husbands' decisionmaking were often strongly criticised by the public opinion. Hillary has never concealed her interest in politics. President Clinton trusted her and respected her opinion; it was Hillary who was appointed to head the Task Force on National Health Care Reform, one of the most important points of the first Clinton's presidency. However, Clinton's presidency was full of financial and sexual scandals which could result in the Americans getting fed up with "Clinton \& Clinton" team.

In January 2009 Mrs Clinton was appointed to be the 67th Secretary of State serving in the administration of Barack Obama. The question is whether the post of the Secretary of State is able to satisfy Hillary's political appetite? It is still possible that Mrs Clinton will re-attempt to run for the top office in the United States. Although it is unlikely for her to fight for the presidency in the next elections, when Obama will try for re-election, it cannot be ruled out that she will later on, under more favourable circumstances.

\section{CONCLUSIONS}

Compared to earlier decades more and more women successfully run for high-profile government posts. Nevertheless, the number of women who become Senators or Governors, allowing them to gain the necessary political experience and make contacts, is still relatively low. Women who opt for self-fulfillment in their professional field tend to do very well in their jobs and have many achievements. There are some professions, however, where women rarely occupy high positions. They include highprofile political and legal posts or senior management of American corporations.

Looking at the women's participation in the political life of the U.S. it is easy to see that the women who are the legislative power-holders often occupy positions through which they can be perceived as being more interested in social issues than men. They often advocate the increase in the state aid for the poorest, single mothers or unemployed. Women's organisations emphasize, however, that women are also equally interested in economic issues, national security or foreign affairs. It is, therefore, vitally important to try and increase women's participation in the U.S. political life. That will allow women to actively influence the quality of law and let them promote issues they find especially important. The women should be interested in politics, as this area of human activity gives them the possibility to advocate issues that can be especially important for women such as the equality of rights, youth education issues or the environment.

\section{REFERENCES}

American Political Leaders 1789-2005 (2005): Congressional Quarterly Inc., Washington D.C. p.77.

Biographical Directory of the U.S. Congress (2011): Women in Congress (http://womenincongress.house.gov/historicaldata/representatives-senators-by-state.html)

Bosacki M. (2010, June 13th): Rok Kobiet, Gazeta Wyborcza.

Center for American Women and Politics (2011): Women appointed to presidential cabinets

(http://www.cawp.rutgers.edu/fast_facts/levels_of_office/documen ts/prescabinet.pdf)

Clinton Rodham H. (2003): Living History. New York: Simon \& Schuster.

Election Center (2008): CNN Politics.com (http://edition.cnn.com/ELECTION/2008/primaries/results/sc orecard/\#D)

Emily's List (2011): (http://www.emilyslist.org)

Gadziński M. (2005, December 3rd): Prezydentka Ameryki, Wysokie Obcasy attachment to „Gazeta Wyborcza”

Green C.H.-Sicherman B. (1980): Notable American Women: The modern Period, Radcliffe College, p.21.

Lopach, J. J.-Luckowski. J. A (2005): Jeannette Rankin: A Political Woman. Boulder, CO: University Press of Colorado.

Malone, D. (1989): Hattie and Huey: An Arkansas Tour. Fayetteville: University of Arkansas Press.
Mildred L.A. (2008): CRS Report for Congress, Women in the United States Congress: 1917-2008 (http://www.senate.gov/reference/resources/pdf/RL30261.pdf) Milewski P. (2010/29): Świat według Hillary, Wprost.

Puerto Rico

(2011):

http://www.topuertorico.org/government.shtml

Talmadge, J. E. (1960): Rebecca Latimer Felton: Nine Stormy Decades. Athens: University of Georgia Press.

U.S. Department of Labor (2009): U.S. Bureau of Labor Statistics, Report 1017, Highlights of Women's Earnings in 2008 (http://www.bls.gov/cps/cpswom2008.pdf)

U. S. House of Representatives (2006): Edith Nourse Rogers in Women in Congress, 1917-2006. Prepared under the direction of the Committee on House Administration by the Office of History \& Preservation, Washington: Government Printing Office.

U. S. House of Representatives (2006): Patsy T. Mink in Women in Congress, 1917-2006. Prepared under the direction of the Committee on House Administration by the Office of History \& Preservation, U. S. House of Representatives. Washington: Government Printing Office.

U.S. Senate (2011): Women in the Senate (http://www.senate.gov/artandhistory/history/common/briefin $\mathrm{g} /$ women_senators.htm)

Women in the Senate and House (2011): (http://www.thewishlist.org/) 